Trakya Eğitim Dergisi

Cilt 9, Sayı 3

Eylül 2019, 612-626

Gelis Tarihi: 11.02.2019

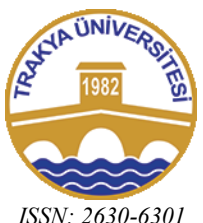

ISSN: 2630-6301
Trakya Journal of Education

Volume 9, Issue 3

September 2019, 612-626

\title{
Hizmetiçi Öğretmenlerin Yansıtıcı Düşünme Eğilimlerinin Çeşitli Değişkenler Açısından İncelenmesi
}

\author{
An Analysis of Teachers' Reflective Thinking Tendencies Depending on Various Variables
}

\author{
Burak AYÇİÇEK ${ }^{1}$, Tuğba YANPAR YELKEN² ${ }^{\text {, Gürol YOKUŞ }}{ }^{3}$
}

\begin{abstract}
Öz: $\mathrm{Bu}$ araştırmanın amacı, öğretmenlerin yansıtıcı düşünme eğilimlerini belirlemek ve çeşitli değişkenler açısından incelemektir. Araştırmanın verileri 'Yansıtıcı Düşünme Eğilimleri Ölçeği' ile toplanmıştır. Tarama modelindeki araştırmanın örneklemini Hatay İli Antakya İlçesi'nde görev yapan 202 öğretmen oluşturmaktadır. Elde edilen bulgulara göre, öğretmenlerin yansıtıcı düşünme eğilimlerinin yüksek olduğu, sürekli ve amaçlı düşünme alt boyutunda kademe değişkenine göre; açık fikirlilik alt boyutunda cinsiyet ve kademe değişkenlerine göre; sorgulayıcı ve etkili öğretim alt boyutunda kademe ve doğdukları bölge değişkenlerine göre; öğretim sorumluluğu ve bilimsellik alt boyutunda kıdem değişkenine göre; araştırmac1 alt boyutunda cinsiyet değişkenine; öngörülü ve içten olma alt boyutunda kıdem değişkenine; mesleğe bakış alt boyutunda cinsiyet, kademe ve bölge değişkenlerine göre anlamlı farklılıklar tespit edilmiştir.
\end{abstract}

Anahtar sözcükler: Yansıtıcı düşünme eğilimi, eğitim inançlarl, sorgulayıcı ögretim.

\begin{abstract}
The purpose of this study is to determine teachers' reflective thinking tendencies. The research data were collected with "The Reflective Thinking Tendency Scale". A survey research has been conducted in the study. Research sample includes 202 teachers in Antakya, a district in Hatay. According to results of teachers' reflective thinking tendencies, continuous and intentional thinking sub-dimension varies according to teachers' teaching level; open-mindedness sub-dimension varies according to gender and teaching level; effective and interrogated teaching subdimension varies according to teaching level and region; responsibility of teaching and science sub-dimension varies according to teachers' seniority; researcher sub-dimension varies according to gender; foresighted and sincere sub-dimension varies depending on seniority; looking professional sub-dimension varies according to gender, teaching level and teachers birthplace region.
\end{abstract}

Keywords: The reflective thinking tendency, educational beliefs, inquiry-based instruction

\section{Introduction}

\section{EXTENDED ABSTRACT}

Teachers with reflective thinking skills tend to use their knowledge both in their daily life and in the classroom setting. It is important for teachers to develop their thinking skills and to use them effectively (Duban, \& Yelken, 2010). One of these significant skills is reflective thinking. In Turkey, there was a change in the framework of education programs in 2005 and the constructivist approach was adopted in the curriculum (Demiralp, 2010). According to the constructivist approach; education should aim to develop reflective thinking skills in individuals (Başol and Evin Gencel, 2013). Ünver (2010) states that reflective thinking is the process of thinking which helps to identify the positive and negative situations that occur in the education process and to solve these problems. Reflective thinking parallels with creative thinking in terms of providing new ideas; with critical thinking in terms of self-evaluation, then parallels with cognitive thinking in terms of thinking on thought and learning (Karadağ, 2010). John Dewey is an important figure in the field of reflective thinking. Stressing the importance of democratic education, John Dewey states that individuals could gain problem-solving and reflective thinking skills with democracy (Genç, 2004).

A teacher who adopts reflective thinking evaluates his / her students better, renews their methods and strategies, self-teach himself after each practice and is open to renewing itself continuously (Rodgers, 2002). Within this respect, Ersözlü (2008) claims that teachers with reflective thinking skills aim to educate students who have an unbiased approach, are sensitive to their environment, are aware of their responsibilities and have problem solving skills. In addition, these teachers provide guidance to students by helping them to learn in a democratic environment. This situation shows that reflective thinking is important in the contemporary education system. In this case, teachers are expected to consciously select, evaluate and continuously improve the practices in the classroom during the learning-teaching process. Reflective thinkers do not accept any information without thinking, criticizing and analyzing (Alp and Taşkın, 2008).

\footnotetext{
1 Dr., Milli Eğitim Bakanlığı, e-posta: aycicekburak@gmail.com, ORCID: 0000-0001-8950-2207

2 Prof. Dr., Mersin Üniversitesi, Eğitim Fakültesi, Eğitim Bilimleri Bölümü, e-posta: tyanpar@gmail.com, ORCID: 0000-00020800-4802

3 Dr., Sinop Üniversitesi, Eğitim Fakültesi, e-posta: gurolyokus@gmail.com, ORCID: 0000-0002-4849-5829
} 
The purpose of this study is to investigate the reflective thinking tendencies of teachers working in primary, secondary and high school education levels in Antakya, Hatay province. For this purpose, the following questions are asked to be answered:

1. What are the level of teachers' reflective thinking tendencies?

2. Do teachers' reflective thinking tendencies differ significantly according to "gender, school level, seniority status, branch and geographical region they were born in"?

\section{Method}

This is a descriptive study using survey model which aims to determine the current situation. The survey model is a research approach that aims to describe a situation that has existed in the past or is still present (Karasar, 2000). In this research, reflective thinking tendencies are attempted to be described in terms of various variables. The data of the study have been obtained from 202 teachers working in Antakya. Teachers in the study group have been selected by random sampling. Since there is no focus on any specific group, random sampling technique has been preferred considering the time and financial limitations (Şimşek and Yıldırım 2004).

Reflective Thinking Tendency Scale (SES): The reflective thinking tendency scale used in the study was developed by Semerci (2007). SES was developed in order to determine the reflective thinking tendencies of in-service teachers and pre-service teachers. This scale consists of 7 sub-scales and 35 items. When the data obtained from 202 teachers are analyzed with "Kolmogorov-Smirnov Normal Distribution Test", it is determined that the data do not show normal distribution in 7 sub-dimensions. In this case, Mann Whitney U Test and Kruskall Wallis Test are preferred which are nonparametric equivalents of Unrelated Samples t Test and ANOVA (Büyüköztürk, 2013; Green and Salkind, 2008).

\section{Result and Discussion}

In the 21st century, teachers are expected to be individuals with critical and reflexive thinking skills and who are capable of interrogating and interpreting knowledge. In this study, it is found out that the reflective thinking tendencies of the teachers are close to the upper level. There are other studies with this finding which indicate that teachers' reflective thinking levels were high (Dolapçığlu, 2007; Aslan, 2009; Aydın and Çelik 2008; Duban, \& Yelken, 2010; Karadağ, 2010; Hasırcı, \& Sadık, 2011, Durdukoca, \& Demir, 2012). When teachers' views on reflective thinking tendencies are examined in terms of gender variable, Open-mindedness, Researcher and Professional perspective subdimensions differ in favor of male teachers. Differences in these sub-dimensions show that male teachers tend to have more tendency to think independently and research. In addition, it has been concluded that this situation affects male teachers' point of view towards their profession. Şanlı (2016) investigates the reflective thinking tendencies of pre-service teachers and significant differences occur depending on gender variable. In parallel with our study, it is observed that male pre-service teachers tend to think more reflective than female teacher candidates, and they get higher scores in terms of Open mindedness and Looking Professional. However, there are other studies which find out no significant difference depending on gender (Dolapçığlu, 2007, Gedik, Akhan and K1lıçoğlu, 2014; Güvenç, 2012; Karadağ, 2010).

According to the teachers' seniority variable, the reflective thinking tendencies of teachers differ in the Responsibility of Teaching \& Science sub-dimension and Foresighted \& Sincere sub-dimension. The findings can be interpreted that the teachers with low seniority act with the responsibility of teaching when they are compared with the senior teachers. They direct the learning process more effectively and consciously and they act on the basis of alternative solutions with flexible programs instead of solid and stable practices. In the study, it is observed that the variable which leads to the most difference appears as teaching level of teachers. In subdimensions of Continuous and intentional thinking, Open-mindedness, Effective and Interrogated Teaching and Looking Professional, secondary and primary school teachers show more reflective thinking tendencies than high-school teachers. This situation might a sign that teachers in primary and secondary schools form an effective education environment for their students and try to ensure that they are actively involved in the educational process. There are some correlations between these subdimension. In a study conducted by Gedik, Akhan and Kılıçoğlu (2014), it is found out that there are high and low correlations between reflective thinking disposition factors in the study. The lowest correlation is 0.450 between Open-mindedness, Effective and Interrogated Teaching; but the highest correlation is 0.733 between Foresighted \& Sincere and Researcher.

The reflective thinking tendencies of the teachers differ according to the region variable, in the subdimensions of Effective and Interrogated Teaching and Looking Professional. The fact that South East Anatolia and Black Sea Regions have lower average compared to other regions can be attributed to the 
strong cultural characteristics, collectivist structure of these regions and more traditional view of education in these regions. Gedik, Akhan and Kılıçoğlu (2014) and Aydın and Çelik (2013) examine whether the family's income led to differentiation in reflective thinking tendencies of pre-service teachers and observe that the socio-economic level of the family do not have an impact on the reflective thinking tendencies of the social studies pre-service teachers. Furthermore, Gedik et al. (2014) find out that social studies preservice teachers' differ significantly in Continuous and Intentional Thinking subdimension according to the type of their high schools and Anatolian High School graduates have the highest levels of continuous and intentional thinking.

\section{GİRIŞ}

21. yüzyılda çağın gerektirdiği niteliklere sahip olabilmek için toplumu oluşturan bireylerin iyi bir eğitim almaları önem arz etmektedir. İçinde bulunduğumuz çağda, bireylerden özdenetime sahip, eleştirel ve yaratıcı düşünen, araştırmacı, öğrenmeyi öğrenmiş ve bilgi teknolojilerini etkili kullanabilen bireyler olmaları beklenmektedir. Semerci'ye (1999) göre, üst düzey düşünme becerilerine sahip olmak başarılı olmak için koşul haline gelmiştir. Bu durum gerek günümüzde gerekse gelecekte zorunluluk olarak kendini göstermektedir. Üst düzey düşünme becerilerine sahip olan bireylerden bilgiyi bilinçli bir şekilde edinmeleri, yorumlamaları ve bu bilgilerden hareketle yeni bilgiler edinmeleri beklenir. Düşünme becerilerine sahip olan birey, sahip olduğu bilgileri amacına uygun olarak hem derste hem de günlük yaşamında kullanmada başarılıdır. Bu becerinin öğrencilere kazandırılabilmesi için öğretmenlerin düşünme becerilerine sahip olmaları ve bu becerileri geliştirip etkili bir şekilde kullanıyor olmaları önem teşkil etmektedir (Duban ve Yelken, 2010). Bu becerilerden biri ise yansitıcı düşünme becerisidir. Ülkemizde 2005 yılında eğitim programlarına yönelik yapılan değişim çerçevesinde, yapılandırmacı yaklaşımın benimsendiği öğretim programları gündeme alınmıştır (Demiralp, 2010). Yapılandırmacı yaklaşıma göre; eğitimin temel amaçlarından biri, bireylerde yansıtıcı düşünme becerilerinin geliştirilmesidir (Başol ve Evin Gencel, 2013).

Yansıtıcı düşünme ile ilgili çalışmalar yapan Dewey (1933), yansıtıcı düşünmeyi "herhangi bir konu üzerinde sürekli ve bilinçli bir şekilde düşünme" olarak tanımlamıştır. Rodgers (2002) ise yansıtıcı düşünme ile ilgili bunun bir döngüyü hatırlattı̆̆ını; uygulama- kuram, kuram-uygulama arasındaki dönüşüme işaret ettiğini ifade etmiştir. Üstünlüoğlu (2006) ise yansıtıcı düşünmeyi, bireyin kendisinin ve başkalarının görüşlerine açık olma, düşüncelerini özgürce dile getirme ve ileri görüşlü olma olarak tanımlamıştır. Eğitim felsefeleriyle ilişkilendirmek gerekirse yansıtıcı düşünme daha çok Amerikan pragmatizmine ve dolayısıyla ilerlemecilik felsefesi ile ilişkili olduğunu söylenebilir (Çubukçu, 2011). Ünver (2010) ise yansıtıcı düşünmeyi problemleri çözme ile ilişkilendirmekte ve kişinin eğitim sürecinde karşılaştı̆ı olumlu ve olumsuz durumları tespit edip çözüm arama amaçlı düşünme süreci olarak açıklamıştır.

Yansıtıcı düşünme; yeni fikirlerin ortaya çıkmasını sağlaması açısından yaratıcı düşünme ile kendini değerlendirmesi açısından eleştirel düşünme ile, düşünce ve öğrenme üzerine düşünmesi açısından ise biliş üstü düşünme ile paralellik göstermektedir (Karadağ, 2010). John Dewey, yansitıcı düşünme alanında önemli bir isimdir. Demokratik eğitimin önemini vurgulayan John Dewey, demokrasi ile bireylerin problem çözme ve yansıtıcı düşünme becerileri kazanabileceğini belirtmiştir (Genç, 2004). Yansıtıcı düşünme bilinçli olarak öğrenilip geliştirilebilen bir beceri olduğu için, uygun eğitim öğretim ortamı oluşturularak bu becerinin kazandırılmasında görev ve sorumluluk öğretmene düşmektedir (Üstün, 2011). Karada ğ (2010), öğretmenlerin yansıtıcı düşünme becerilerini öğrencilere kazandırabilmeleri için öncelikle bu beceriyi içselleştirmiş olması gerektiğini vurgulayarak, eğitim ortamının demokratik ve öğrenci merkezli olup olmamasının öğretmene bağlı olduğunu belirtmektedir. Bu noktada, yansıtıcı düşünme gibi bir üst düzey düşünme becerisinden geleneksel yöntemlerden farkını incelemekte fayda vardır. Ünver'e (2010) göre, öğretmen geleneksel öğrenmede bilgi verici rolündeyken, yansıtıcı öğrenmede kolaylaştırıc1 rolündedir. Geleneksel öğrenmede öğrenme ortamını öğretmen yönetirken, yansıtıcı öğrenmede işbirlikli bir anlayış hâkimdir. Geleneksel öğrenmede öğretmenin öğrencinin hatalarını düzelttiği tek taraflı bir iletişim varken, yansıtıcı düşünmede iki yönlü ve olumlu bir iletişim vardır. Geleneksel öğrenmenin başarı göstergesi test puanları iken, yansıtıcı öğrenmenin başarı göstergesi öğrencinin görüşlerini demokratik bir ortamda özgürce ifade etme becerisidir.

Yansıtıcı eğitim sisteminde öğrenciler, eğitim öğretim uygulamalarının merkezinde yer alırlar, kendi öğrenmelerinden sorumluluk duyarlar ve demokratik bir sınıf ortamında fikirlerini özgürce dile getirebilirler (Ünver, 2010). Yansıtıcı düşünmeyi benimsemiş bir öğretmen, öğrencilerini daha iyi değerlendirerek, yöntem ve stratejilerini yeniler, her uygulamasından sonra kendisine sonuçlar çıkarır ve 
sürekli olarak kendini yenilemeye açıktır (Rodgers, 2002). Bu görüşe paralel olarak, Ersözlü’ye (2008) göre, yansıtıcı düşünme becerilerine sahip olan öğretmenler; önyargısız bir bakış açısına sahip, çevreye duyarlı, sorumluluklarının bilincinde, problem çözme becerilerine sahip öğrenciler yetiştirmeyi amaçlamaktadır. Ayrıca, bu öğretmenler öğrencilerin demokratik bir ortamda eğitim almalarına yardım ederek onlara rehberlik yapmaktadır. Bu bilgiler, yansıtıcı düşünmenin çağdaş eğitim sistemi içerisinde önemli bir yerde olduğunu göstermektedir. Bu durumda öğretmenlerin öğrenme-öğretme sürecinde sınıf içindeki uygulamaları bilinçli bir şekilde seçmeleri, değerlendirmeleri ve söz konusu uygulamaları sürekli geliştirme çabasında olmaları beklenmektedir. Yansitıcı düşünen öğretmen bilgiyi kesin olarak kabul etmez, düşünür, eleştirir, sorgular ve analiz eder (Alp ve Taşkın, 2008).

Yansıtıcı düşünmenin hâkim olduğu sınıf ortamlarının oluşması noktasında öğretmen ve okul tarafından benimsenen eğitim inançlarının önemli bir yeri vardır. İnanç, bireyin yaşamda karşılaşmış olduğu çeşitli türden olay, olgu, özne ya da objeyi algılamasını, anlamlandırmasını ve ona karşı tutumunu belirleyen kabuller şeklinde tanımlanmaktadır (Deryakulu, 2004). Son yıllarda gerek yurt dışında gerekse ülkemizde, araştırmacılar tarafından yansıtıcı düşünme becerisinin geliştirilmesine yönelik araştırmalara karşı bir ilgi vardır. Bu durum, yansıtıcı düşünmenin, öğretmenler açısından önemli bir düşünme biçimi olmasından kaynaklanmaktadır. Bu araştırmanın da temel konusunu oluşturan yansıtıcı düşünmeyi öğretmenler açısından ele almakta faydalı olacaktır. $\mathrm{Bu}$ nedenle, öğretmenlerin yansitıcı düşünme eğilimlerinin incelenmesinin alan yazındaki bu boşluğu doldurması ve araştırmacı ve uygulayıcılara önemli yararlar sağlaması beklenmektedir.

$\mathrm{Bu}$ araştırmanın amacı Hatay iline bağlı Antakya ilçesinde ilkokul, ortaokul ve lise öğretim kademelerinde görev yapan öğretmenlerin yansıtıcı düşünme eğilimlerinin incelemektir. Bu amaç doğrultusunda aşağıdaki sorulara cevap aranacaktır;

1. Öğretmenlerin yansıtıcı düşünme eğilimleri ne düzeydedir?

2. Öğretmenlerin yansıtıcı düşünme eğilimleri, "cinsiyet, okul kademesi, kıdem durumu, branş ve doğdukları coğrafi bölge" değişkenlerine göre anlamlı farklılık göstermekte midir?

\section{YÖNTEM}

$\mathrm{Bu}$ çalışma, var olan durumu saptamak amacıyla tarama (survey) modeli kullanılarak yapılan betimsel bir çalışmadır. Tarama modeli, geçmişte veya halen var olan bir durumu var olduğu şekliyle betimlemeyi amaçlayan araştırma yaklaşımıdır (Karasar, 2000). Bu araştırmada yansıtıcı düşünme eğilimleri çeşitli değişkenler bakımından betimlenmeye çalışılmıştır.

\subsection{Araştırma Grubu}

Araştırmanın verileri Hatay Antakya'da görev yapan 202 öğretmeninden elde edilmiştir. Çalışma grubundaki öğretmenler rastgele örnekleme yoluyla seçilmiştir. Öğretmenler arasında belirli bir grup incelenmediğinden zaman ve maddi sinırlılıklar da göz önünde bulundurularak seçkisiz örnekleme tekniği kullanılmıştır (Şimşek ve Yıldırım 2004). Araştırma grubunun sahip olduğu demografik değişkenler Tablo 1'de yer almaktadır:

Tablo 1. Çalışma Grubuna İlișkin Demografik Değişkenler

\begin{tabular}{|c|c|c|c|}
\hline & & $\mathbf{N}$ & $\%$ \\
\hline \multirow{2}{*}{ Cinsiyet } & Kadın & 112 & 55,4 \\
\hline & Erkek & 90 & 44,6 \\
\hline \multirow{3}{*}{ Öğretim Kademesi } & İlkokul & 53 & 26,2 \\
\hline & Ortaokul & 84 & 41,6 \\
\hline & Lise & 65 & 32,2 \\
\hline \multirow{3}{*}{ Kidem yilı } & $1-10 \mathrm{y} 1 \mathrm{l}$ & 85 & 42,1 \\
\hline & $11-20 \mathrm{y} 1 \mathrm{l}$ & 71 & 35,1 \\
\hline & 21 yıl ve üzeri & 46 & 22,8 \\
\hline \multirow{5}{*}{ Branş } & Sinıf Öğrt. & 53 & 26,2 \\
\hline & Matematik Öğrt. & 22 & 10,9 \\
\hline & İngilizce Öğrt. & 21 & 10,4 \\
\hline & Türkçe Öğrt. & 20 & 9,9 \\
\hline & Sosyal Bilgiler Öğrt. & 25 & 12,4 \\
\hline
\end{tabular}




\begin{tabular}{llll}
\hline & \multicolumn{1}{c}{ Fen Öğrt. } & 21 & 10,4 \\
\cline { 2 - 4 } & Din Kültürü ve Ahlak Öğrt. & 22 & 10,9 \\
\cline { 2 - 4 } & Diğer & 18 & 8,9 \\
\hline \multirow{5}{*}{ Dŏgduğu Bölge } & Akdeniz & 51 & 25,2 \\
\cline { 2 - 4 } & Ege & 23 & 11,4 \\
\cline { 2 - 4 } & Doğu Anadolu & 32 & 12,4 \\
\cline { 2 - 4 } & İç Anadolu & 25 & 13,9 \\
\cline { 2 - 4 } & Güney Doğu & 28 & 12,9 \\
\cline { 2 - 4 } & Marmara & 26 & 8,4 \\
\cline { 2 - 4 } & Karadeniz & 17 & 100 \\
\hline Toplam & & 202 & \\
\hline
\end{tabular}

\subsection{Veri Toplama Aracı}

Yansıtıcı Düşünme Eğilimi Ölçeği (YDEÖ): Çalışma kapsamında veri toplamak için kullanılan yansıtıcı düşünme eğilimi ölçeği (YDEÖ) Semerci (2007) tarafından geliştirilmiştir. Bu ölçek, öğretmen ve öğretmen adaylarının yansıtıcı düşünme eğilimlerini belirleyebilmek amacıyla geliştirilmiştir. Yansıtıcı Düşünme Eğilimi Ölçeği "kesinlikle katılıyorum"dan "kesinlikle katılmıyorum"a kadar dereceleme yapan 5'li likert türünde tasarlanmıştır. Ölçek, Sürekli ve Amaçı Düşünme, Açık Fikirlilik, Sorgulayıcı ve Etkili Öğretim, Öğretim Sorumluluğu ve Bilimsellik, Araştırmacı, Öngörülü ve İçten Olma ve Mesleğe Bakış olmak üzere 7 alt ölçek ve toplam 35 maddeden oluşmaktadır.

\subsection{Verilerin Analizi}

202 öğretmene uygulanan ölçeklerden elde edilen veriler analiz edildiğinde Yansıtıcı Düşünme Eğilimi Ölçeğinin 7 alt boyutunda da "Kolmogorov-Smirnov Normal Dağılım Testi" sonucunda, verilerin normal dağılım göstermediği belirlenmiştir. Bu durumda İlişkisiz Örneklemler T-Testi ve ANOVA yerine, bu testlerin parametrik olmayan karşılıkları olan Mann Whitney U Test ve Kruskall Wallis Test uygulanmıştır (Büyüköztürk, 2013; Green ve Salkind, 2008). Kolmogorov-Smirnov Normal Dağılım Testi sonuçları Tablo 2'de gösterilmiştir.

Tablo 2. Kolmogorov-Smirnov (KS) Normal Dağılım Testi Sonuçları

\begin{tabular}{l|l|l|l}
\hline Yansıtıcı Düşünme Eğilimi Altölçekleri & $\mathrm{N}$ & $\mathrm{sd}$ & $\mathrm{p}$ \\
\hline Sürekli ve Amaçı Düşünme (SAD) & 202 & 202 & 0.001 \\
\hline Açık Fikirlilik (AF) & 202 & 202 & 0.000 \\
\hline Sorgulayıcı ve Etkili Öğretim (SEÖ) & 202 & 202 & 0.000 \\
\hline Öğretim Sorumluluğu ve Bilimsellik (ÖSB) & 202 & 202 & 0.001 \\
\hline Araştırmacı (A) & 202 & 202 & 0.000 \\
\hline Öngörülü ve İçten Olma (ÖİO) & 202 & 202 & 0,000 \\
\hline Mesleğe Bakış (MB) & 202 & 202 & 0,000 \\
\hline
\end{tabular}

Tablo 2'de yer alan Kolmogorov-Smirnov testi sonucu incelendiğinde; yansıtıcı düşünme eğilimi ölçeğinin (YDEÖ) 7 alt boyutunda elde edilen verilerin test sonuçlarının anlamlı olduğu $(\mathrm{p}<.05)$; dolayısıyla verilerin normal dağılım göstermediğini görülmektedir.

\section{BULGULAR}

Araştırmada kullanılan "Yansıtıcı Düşünme Eğilimleri Ölçeği” ve bu alt ölçeklerden katılımcıların aldıkları puanların betimsel istatistikleri Tablo 3'te gösterilmiştir. 
Tablo 3. "Yansıtıcı Düşünme Eğilimi Ölçeği”ne Ait Betimsel İstatistikler

\begin{tabular}{lcccccc}
\hline \multicolumn{1}{c}{ Altölçekler } & N & $\bar{X}$ & Mod & SS & Minimum & Maksimum \\
\hline Sürekli ve Amaçlı Düşünme (SAD) & 202 & 27,25 & 29 & 3,76 & 19 & 35 \\
\hline Açık Fikirlilik (AF) & 202 & 23,73 & 30 & 5,14 & 7 & 30 \\
\hline Sorgulayıcı ve Etkili Öğretim (SEÖ) & 202 & 20,18 & 21 & 3,19 & 11 & 25 \\
\hline Öğretim Sorumluluğu ve Bilimsellik (ÖSB) & 202 & 20,19 & 21 & 2,29 & 13 & 25 \\
\hline Araştırmacı (A) & 202 & 24,74 & 25 & 3,13 & 13 & 30 \\
\hline Öngörülü ve İçten Olma (ÖİO) & 202 & 16,76 & 18 & 2,35 & 8 & 20 \\
\hline Mesleğe Bakış (MB) & 202 & 7,79 & 10 & 2,26 & 2 & 10 \\
\hline
\end{tabular}

Tablo 3'te yer alan ortalama ve mod değerleri incelendiğinde elde edilen bulgular maddeler halinde şöyle özetlenmektedir:

- Öğretmenlerin Sürekli ve Amaçlı Düşünme altölçeğinden alabilecekleri en yüksek puan 35 iken ortalamanın 27,25 olduğu görülmüş̧ür. Mod ise 29'dur. Öğretmenlerin ortalamadan daha yüksek puana yığıldığı ve sürekli ve amaçlı düşünme eğilimlerinin yüksek olduğu belirlenmiştir.

- Öğretmenlerin Açık Fikirlilik altölçeğinden alabilecekleri en yüksek puan 30 iken ortalamanın 23,73 olduğu görülmüştür. Mod ise 30 'dir. Öğretmenlerin ortalamadan daha yüksek puana yığıldığı ve açık fikirlilik eğilimlerinin yüksek olduğu belirlenmiştir.

- Öğretmenlerin Sorgulayıcı ve Etkili Öğretim altölçeğinden alabilecekleri en yüksek puan 25 iken ortalamanın 20,18 olduğu görülmüştür. Mod ise 21'dir. Öğretmenlerin ortalamadan daha yüksek puana yığıldığ 1 ve sorgulayıc1 ve etkili ögretim eğiliminde oldukları belirlenmiştir.

- Öğretmenlerin Öğretim Sorumluluğu ve Bilimsellik altölçeğinden alabilecekleri en yüksek puan 25 iken ortalamanın 20,19 olduğu görülmüştür. Mod ise 21'dir. Öğretmenlerin ortalamadan daha yüksek puana yığıldığı ve öğretim sorumluluğu ve bilimsellik eğilimlerinin yüksek olduğu belirlenmiştir.

- Öğretmenlerin Araştırmacı altölçeğinden alabilecekleri en yüksek puan 30 iken ortalamanın 24,74 olduğu görülmüştür. Mod ise $25^{\prime}$ tir. Öğretmenlerin ortalamadan daha yüksek puana yığıldığı ve araştırmacı eğiliminde oldukları belirlenmiştir.

- Öğretmenlerin Öngörülü ve İçten Olma altölçeğinden alabilecekleri en yüksek puan 20 iken ortalamanın 16,76 olduğu görülmüştür. Mod ise 18'dir. Öğretmenlerin ortalamadan daha yüksek puana yığıldığı ve öğretim örgütlü ve içten olma eğilimlerinin yüksek olduğu belirlenmiştir.

- Öğretmenlerin Mesleğe Bakış altölçeğinden alabilecekleri en yüksek puan 10 iken ortalamanın 7,79 olduğu görülmüsstür. Mod ise 10 'dur. Öğretmenlerin ortalamadan daha yüksek puana yığıldığı ve mesleğe bakış eğilimlerinin olumlu olduğu belirlenmiştir.

\section{Öğretmenlerin Yansıtıcı Düşünme Eğilimlerinin Çeşitli Değişkenlere Göre İncelenmesi}

Araştırmada öğretmenlerin yansıtıcı düşünme eğilimlerinin hangi değişkenlere göre farklılaştı̆g incelenmiştir. Elde edilen verilerde normal dağılım olmadığ için Mann Whitney U Testi ve Kruskal Wallis Testi ile gerçekleştirilmiştir. Sürekli ve Amaçlı Düşünme altölçeğine ilişkin analiz sonuçları Tablo 4'te özetlenmiştir.

Tablo 4. Sürekli ve Amaçlı Düşünme (SAD) değişkeninin çeşitli değişkenlere göre değiş̧imi

\begin{tabular}{|c|c|c|c|c|c|c|c|c|}
\hline & Değişkenler & $\mathbf{N}$ & $\bar{X}$ & $\begin{array}{c}\text { Mann } \\
\text { Whitney } \\
\text { U }\end{array}$ & $\begin{array}{c}\text { Kruskal } \\
\text { Wallis } X^{2}\end{array}$ & sd & $\mathbf{p}$ & $\begin{array}{l}\text { Farklılığın } \\
\text { manidarlığı }\end{array}$ \\
\hline \multirow{14}{*}{ 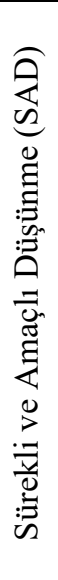 } & 1.Kadın & 112 & 27,04 & \multirow{2}{*}{4755,000} & \multirow{2}{*}{---} & \multirow{2}{*}{---} & \multirow{2}{*}{0,589} & \\
\hline & 2.Erkek & 90 & 27,51 & & & & & \\
\hline & 1.İlkokul & 53 & 27,17 & \multirow{3}{*}{--- } & \multirow{3}{*}{8,718} & \multirow{3}{*}{2} & \multirow{3}{*}{0,013} & \multirow{3}{*}{$2-3$} \\
\hline & 2.Ortaokul & 84 & 28,01 & & & & & \\
\hline & 3.Lise & 65 & 26,34 & & & & & \\
\hline & $1.1-10 Y_{11}$ & 85 & 27,01 & \multirow{3}{*}{---} & \multirow{3}{*}{0,761} & \multirow{3}{*}{2} & \multirow{3}{*}{0,683} & \\
\hline & 2.11-20 Y1l & 71 & 27,18 & & & & & \\
\hline & 3.21 Y1l ve Ustu & 46 & 27,80 & & & & & \\
\hline & 1.Sınıf Öğretmeni & 53 & \multirow{2}{*}{$\begin{array}{l}27,55 \\
27,05\end{array}$} & \multirow{6}{*}{---} & \multirow{6}{*}{5,443} & \multirow{6}{*}{7} & \multirow{6}{*}{0,606} & \\
\hline & 2.Matematik & 22 & & & & & & \\
\hline & 3.İngilizce & 21 & 27,57 & & & & & \\
\hline & 4.Türkçe & 20 & 28,60 & & & & & \\
\hline & 5.Sosyal Bilgiler & 25 & 26,80 & & & & & \\
\hline & 6.Fen Bilimleri & 21 & 27,33 & & & & & \\
\hline
\end{tabular}




\begin{tabular}{|c|c|c|c|c|c|c|}
\hline 7.Din Kültürü & 22 & 26,09 & & & & \\
\hline 8.Diger & 18 & 26,72 & & & & \\
\hline 1.Akdeniz & 51 & 27,96 & & & & \\
\hline 2.Ege & 23 & 27,26 & & & & \\
\hline 3.Doğu Anadolu & 32 & 26,44 & & & & \\
\hline 4.İç Anadolu & 25 & 28,44 & --- & 11,842 & 6 & 0,066 \\
\hline 5.Güneydoğu Anadolu & 28 & 27,82 & & & & \\
\hline 6.Marmara & 26 & 25,96 & & & & \\
\hline 7.Karadeniz & 17 & 25,94 & & & & \\
\hline
\end{tabular}

Tablo 4 incelendiğinde, cinsiyetin (MWU=4755,000, p>.05), öğretmenin sahip olduğu kıdemin $\left(X^{2}=0,761, p>.05\right)$, öğretmenin branşının $\left(X^{2}=5,443, p>.05\right)$ ve öğretmenin dünyaya geldiği coğrafi bölgenin $\left(X^{2}=11,842, p>.05\right)$ Sürekli ve Amaçlı Düşünme altölçeğinde (SAD) anlamlı farklılık yaratmadığ 1 görülmüştür. Fakat öğretmenin çalıştı̆̆ öğretim kademesinin Sürekli ve Amaçlı Düşünme altölçeğinde anlamlı farklılık yarattığı $\left(X^{2}=8,718, p<.05\right)$ görülmüştür. Bu farklılık ortaokulda çalışan öğretmenlerle ( $\bar{X}=28,01)$ lisede çalışan öğretmenler $(\bar{X}=26,34)$ arasında, ortaokulda çalışan öğretmenler lehinedir. Açık Fikirlilik altölçeğine ilişkin analiz sonuçları Tablo 5 'te özetlenmiştir.

Tablo 5. Çeşitli Değişkenler Bakımından Açık Fikirlilik (AF)

\begin{tabular}{|c|c|c|c|c|c|c|c|c|}
\hline & Değişkenler & $\mathbf{N}$ & $\bar{X}$ & $\begin{array}{c}\text { Mann } \\
\text { Whitney } \\
\text { U }\end{array}$ & $\begin{array}{c}\text { Kruskal } \\
\text { Wallis } X^{2}\end{array}$ & sd & $\mathbf{P}$ & $\begin{array}{c}\text { Anlamlı } \\
\text { Fark }\end{array}$ \\
\hline \multirow{23}{*}{ 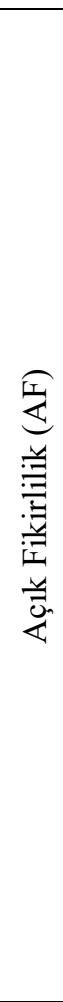 } & 1.Kadın & 112 & 23,03 & \multirow[b]{2}{*}{3938,500} & \multirow[b]{2}{*}{---} & \multirow[b]{2}{*}{--- } & \multirow{2}{*}{0,007} & \multirow{2}{*}{$1-2$} \\
\hline & 2.Erkek & 90 & 24,60 & & & & & \\
\hline & 1.İlkokul & 53 & 24,85 & \multirow{3}{*}{---} & \multirow{3}{*}{8,004} & \multirow{3}{*}{2} & \multirow{3}{*}{0,018} & \multirow{6}{*}{$1-3$} \\
\hline & 2.Ortaokul & 84 & 24,24 & & & & & \\
\hline & 3.Lise & 65 & 22,15 & & & & & \\
\hline & $1.1-10 \mathrm{Y}_{11}$ & 85 & 23,14 & \multirow{3}{*}{---} & \multirow{3}{*}{1,138} & \multirow{3}{*}{2} & \multirow{3}{*}{0,566} & \\
\hline & $2.11-20 \mathrm{Y}_{11}$ & 71 & 23,99 & & & & & \\
\hline & 3.21 Y1l ve Ustu & 46 & 24,41 & & & & & \\
\hline & 1.Sınıf Öğretmeni & 53 & 24,57 & \multirow{8}{*}{---} & \multirow{8}{*}{5,517} & \multirow{8}{*}{7} & \multirow{8}{*}{0,597} & \\
\hline & 2.Matematik & 22 & 23,00 & & & & & \\
\hline & 3.İngilizce & 21 & 23,86 & & & & & \\
\hline & 4.Türkçe & 20 & 22,20 & & & & & \\
\hline & 5.Sosyal Bilgiler & 25 & 24,68 & & & & & \\
\hline & 6.Fen Bilimleri & 21 & 24,29 & & & & & \\
\hline & 7.Din Kültürü & 22 & 22,14 & & & & & \\
\hline & 8.Diger & 18 & 23,67 & & & & & \\
\hline & 1.Akdeniz & 51 & 23,47 & \multirow{7}{*}{---} & \multirow{7}{*}{10,669} & \multirow{7}{*}{6} & \multirow{7}{*}{0,599} & \\
\hline & 2.Ege & 23 & 23,83 & & & & & \\
\hline & 3.Doğu Anadolu & 32 & 22,13 & & & & & \\
\hline & 4.İç Anadolu & 25 & 25,68 & & & & & \\
\hline & 5.Güneydoğu Anadolu & 28 & & & & & & \\
\hline & 6.Marmara & 26 & & & & & & \\
\hline & 7.Karadeniz & 17 & & & & & & \\
\hline
\end{tabular}

Tablo 5 incelendiğinde, öğretmenin sahip olduğu kıdemin $\left(X^{2}=1,138, p>.05\right)$, öğretmenin branşının $\left(X^{2}=5,517, \mathrm{p}>.05\right)$ ve öğretmenin dünyaya geldiği coğrafi bölgenin $\left(X^{2}=10,669, \mathrm{p}>.05\right)$ Açık Fikirlilik altölçeğinde anlamlı farklılık yaratmadığı görülmüştür. Fakat cinsiyetin (MWU=3938,500, $\mathrm{p}<.05)$ ve öğretmenin çalıştığı öğretim kademesinin $\left(X^{2}=8,004, \mathrm{p}<.05\right)$ Açık Fikirlilik altölçeğinde anlamlı farklılık yarattığı görülmüştür. Bu farklılık kadın öğretmenlerle $(\bar{X}=23,03)$ erkek öğretmenler $(\bar{X}=24,60)$ arasında erkek öğretmenler lehinedir. Ayrıca bu farklılık ilkokulda çalışan öğretmenlerle $(\bar{X}=24,85)$ lisede çalışan öğretmenler ( $\bar{X}=22,15)$ arasında ilkokulda çalışan öğretmenler lehinedir. Sorgulayıcı ve Etkili Öğretim altölçeğine ilişkin analiz sonuçları Tablo 6'da özetlenmiştir. 
Tablo 6. Çeşitli Değişkenler Bakımından Sorgulayııı ve Etkili Öğretim (SEÖ)

\begin{tabular}{|c|c|c|c|c|c|c|c|c|}
\hline & Değişkenler & $\mathbf{N}$ & $\bar{X}$ & $\begin{array}{c}\text { Mann } \\
\text { Whitney } \\
\text { U }\end{array}$ & $\begin{array}{c}\text { Kruskal } \\
\text { Wallis } X^{2}\end{array}$ & sd & $\mathbf{p}$ & $\underset{\text { Fark }}{\text { Anlamlı }}$ \\
\hline \multirow{23}{*}{ 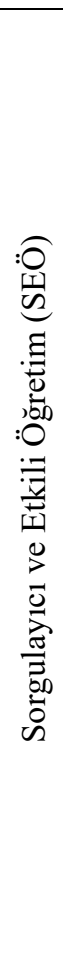 } & 1.Kadın & 112 & 19,96 & \multirow{2}{*}{4485,000} & \multirow{2}{*}{---} & \multirow{2}{*}{---} & \multirow{2}{*}{0,177} & \\
\hline & 2.Erkek & 90 & 20,46 & & & & & \\
\hline & 1.İlkokul & 53 & 20,81 & \multirow{3}{*}{---} & \multirow{3}{*}{11,470} & \multirow{3}{*}{2} & \multirow{3}{*}{0,003} & \multirow{3}{*}{$1-3,2-3$} \\
\hline & 2.Ortaokul & 84 & 20,62 & & & & & \\
\hline & 3.Lise & 65 & 19,09 & & & & & \\
\hline & $1.1-10 Y_{11}$ & 85 & 20,22 & \multirow{3}{*}{---} & \multirow{3}{*}{0,115} & \multirow{3}{*}{2} & \multirow{3}{*}{0,944} & \\
\hline & 2.11-20 Yil & 71 & 20,17 & & & & & \\
\hline & 3.21 Yil ve Ustu & 46 & 20,11 & & & & & \\
\hline & 1.Sınıf Öğretmeni & 53 & 20,47 & \multirow{8}{*}{---} & \multirow{8}{*}{8,485} & \multirow{8}{*}{7} & \multirow{8}{*}{0,292} & \\
\hline & 2.Matematik & 22 & 19,59 & & & & & \\
\hline & 3.İngilizce & 21 & 21,00 & & & & & \\
\hline & 4.Türkçe & 20 & 19,85 & & & & & \\
\hline & 5.Sosyal Bilgiler & 25 & 19,80 & & & & & \\
\hline & 6.Fen Bilimleri & 21 & 20,71 & & & & & \\
\hline & 7.Din Kültürü & 22 & 18,86 & & & & & \\
\hline & 8.Diger & 18 & 20,94 & & & & & \\
\hline & 1.Akdeniz & 51 & 20,33 & \multirow{7}{*}{--- } & \multirow{7}{*}{17,143} & \multirow{7}{*}{6} & \multirow{7}{*}{0,009} & \multirow{7}{*}{$2-3,3-4$} \\
\hline & 2.Ege & 23 & 21,22 & & & & & \\
\hline & 3.Doğu Anadolu & 32 & 21,63 & & & & & \\
\hline & 4.İç Anadolu & 25 & 21,12 & & & & & \\
\hline & 5.Güneydoğu Anadolu & 28 & 19,89 & & & & & \\
\hline & 6.Marmara & 26 & 21,00 & & & & & \\
\hline & 7.Karadeniz & 17 & 19,06 & & & & & \\
\hline
\end{tabular}

Tablo 6 incelendiğinde, cinsiyetin (MWU $=4485,000, p>.05$ ), öğretmenin sahip olduğu k1demin $\left(X^{2}=0,115, \mathrm{p}>.05\right)$ ve öğretmenin branşının $\left(X^{2}=8,485, \mathrm{p}>.05\right)$ Sorgulayıcı ve Etkili Öğrenme altölçeğinde anlamlı farklılık yaratmadığı görülmüştür. Fakat öğretmenin çalıştığı öğretim kademesinin $\left(X^{2}=11,470\right.$, $\mathrm{p}<.05)$ ve öğretmenin dünyaya geldiği coğrafi bölgenin $\left(X^{2}=17,143, \mathrm{p}<.05\right)$ Sorgulayıc1 ve Etkili Öğrenme altölçeği açısından anlamlı farklılık yarattı̆̆g görülmüştür. Bu farklılık ilkokulda çalışan öğretmenlerle ( $\bar{X}$ $=20,81)$ lisede çalışan öğretmenler $(\bar{X}=19,09)$ arasında ilkokulda çalışan öğretmenler lehinedir. Ortaokulda çalışan öğretmenlerle ( $\bar{X}=20,62)$ lisede çalışan öğretmenler $(\bar{X}=19,09)$ arasında ortaokulda çalışan öğretmenler lehinedir. Ayrıca, Ege Bölgesi’nde dünyaya gelen öğretmenler $(\bar{X}=21,22)$ Doğu Anadolu Bölgesi'nde dünyaya gelen öğretmenlere göre $(\bar{X}=18,63)$ Sorgulayıcı ve Etkili Öğrenme altölçeğinde daha yüksek ortalamalara sahiptir. İç Anadolu Bölgesi'nde dünyaya gelen öğretmenler de $(\bar{X}$ $=21,12)$ Doğu Anadolu Bölgesi'nde dünyaya gelen öğretmenlere göre $(\bar{X}=18,63)$ daha yüksek ortalamalara sahiptirler. Öğretim Sorumluluğu ve Bilimsellik altölçeğine ilişkin analiz sonuçları Tablo 7'de özetlenmiştir.

Tablo 7. Çeşitli Değişkenler Bakımından Öğretim Sorumluluğu ve Bilimsellik (ÖSB)

\begin{tabular}{|c|c|c|c|c|c|c|c|c|}
\hline & Değişkenler & $\mathbf{N}$ & $\bar{X}$ & $\begin{array}{c}\text { Mann } \\
\text { Whitney } \\
\text { U }\end{array}$ & $\begin{array}{c}\text { Kruskal } \\
\text { Wallis } X^{2}\end{array}$ & sd & $\mathbf{p}$ & $\underset{\text { Fark }}{\text { Anlamlı }}$ \\
\hline \multirow{9}{*}{ 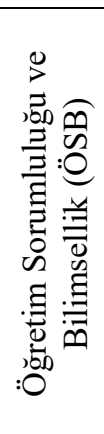 } & 1.Kadın & $\frac{112}{90}$ & $\begin{array}{l}20,18 \\
2022\end{array}$ & 4949,000 & --- & --- & 0,824 & \\
\hline & 1.İlkokul & 53 & 19,87 & \multirow{3}{*}{ 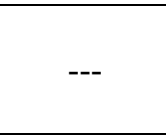 } & \multirow{3}{*}{3,525} & \multirow{3}{*}{2} & \multirow{3}{*}{0,172} & \\
\hline & 2.Ortaokul & 84 & 20,57 & & & & & \\
\hline & 3.Lise & 65 & 19,98 & & & & & \\
\hline & 1.1-10 Y1l & 85 & 20,72 & \multirow{3}{*}{---} & \multirow{3}{*}{12,013} & \multirow{3}{*}{2} & \multirow{3}{*}{0,002} & \multirow{3}{*}{$1-3$} \\
\hline & 2.11-20 Yil & 71 & 20,18 & & & & & \\
\hline & 3.21 Yil ve Ustu & 46 & 19,26 & & & & & \\
\hline & 1.Sınıf Öğretmeni & 53 & 20,47 & \multirow{2}{*}{---} & \multirow{2}{*}{7,368} & \multirow{2}{*}{7} & \multirow{2}{*}{0,392} & \\
\hline & 2.Matematik & 22 & 20,09 & & & & & \\
\hline
\end{tabular}




\begin{tabular}{|c|c|c|}
\hline 3.İngilizce & 21 & 20,38 \\
\hline 4.Türkçe & 20 & 21,00 \\
\hline 5.Sosyal Bilgiler & 25 & 19,64 \\
\hline 6.Fen Bilimleri & 21 & 19,29 \\
\hline 7.Din Kültürü & 22 & 20,41 \\
\hline 8.Diger & 18 & 20,00 \\
\hline 1.Akdeniz & 51 & 20,43 \\
\hline 2.Ege & 23 & 21,26 \\
\hline 3.Doğu Anadolu & 32 & 19,88 \\
\hline 4.İç Anadolu & 25 & 19,52 \\
\hline 5.Güneydoğu Anadolu & 28 & 19,43 \\
\hline 6.Marmara & 26 & 20,35 \\
\hline 7.Karadeniz & 17 & 20,71 \\
\hline
\end{tabular}

Tablo 7 incelendiğinde, cinsiyetin (MWU=4949,000, p>.05), öğretmenin çalıştığ1 öğretim kademesinin $\left(X^{2}=3,525, \mathrm{p}>.05\right)$, öğretmenin branşının $\left(X^{2}=7,368, \mathrm{p}>.05\right)$ ve öğretmenin dünyaya geldiği coğrafi bölgenin $\left(X^{2}=9,964, \mathrm{p}>.05\right)$ Öğretim Sorumluluğu ve Bilimsellik altölçeğinde anlamlı farklılık yaratmadığı görülmüştür. Fakat öğretmenin kıdeminin Öğretim Sorumluluğu ve Bilimsellik açısından anlamlı farklılık yarattı̆̆ görülmüştür $\left(X^{2}=12,013, \mathrm{p}<.05\right)$. Bu farkl11ık 1-10 yıl kıdeme sahip öğretmenlerle $(\bar{X}=20,72) 21$ yıl ve üstü kıdeme sahip öğretmenler $(\bar{X}=19,26)$ arasında 1-10 yıl kıdeme sahip öğretmenler lehinedir. Araştırmacı altölçeğine ilişkin analiz sonuçları Tablo 8'de özetlenmiştir.

Tablo 8. Çeşitli Değişkenler Bakımından Araştırmacı (A)

\begin{tabular}{|c|c|c|c|c|c|c|c|c|}
\hline & Değişkenler & $\mathbf{N}$ & $\bar{X}$ & $\begin{array}{c}\text { Mann } \\
\text { Whitney } \\
\text { U }\end{array}$ & $\begin{array}{c}\text { Kruskal } \\
\text { Wallis } X^{2}\end{array}$ & sd & $\mathbf{p}$ & $\begin{array}{c}\text { Anlamlı } \\
\text { Fark }\end{array}$ \\
\hline \multirow{23}{*}{ 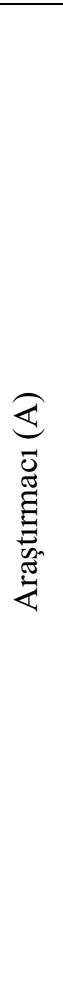 } & 1.Kadın & 112 & 24,30 & \multirow[b]{2}{*}{3990,500} & \multirow[b]{2}{*}{---} & \multirow[b]{2}{*}{---} & \multirow[b]{2}{*}{0,011} & \multirow[b]{2}{*}{$1-2$} \\
\hline & 2.Erkek & 90 & 25,28 & & & & & \\
\hline & 1.İlkokul & 53 & 24,53 & \multirow{3}{*}{---} & \multirow{3}{*}{1,601} & \multirow{3}{*}{2} & \multirow{3}{*}{0,449} & \\
\hline & 2.Ortaokul & 84 & 24,62 & & & & & \\
\hline & 3.Lise & 65 & 25,06 & & & & & \\
\hline & $1.1-10 \mathrm{Y}_{11}$ & 85 & 25,07 & \multirow{3}{*}{---} & \multirow{3}{*}{3,673} & \multirow{3}{*}{2} & \multirow{3}{*}{0,159} & \\
\hline & $2.11-20 \mathrm{Y}_{11}$ & 71 & 24,46 & & & & & \\
\hline & 3.21 Yil ve Ustu & 46 & 24,54 & & & & & \\
\hline & 1.Sınıf Öğretmeni & 53 & 24,91 & \multirow{8}{*}{---} & \multirow{8}{*}{10,828} & \multirow{8}{*}{7} & \multirow{8}{*}{0,146} & \\
\hline & 2.Matematik & 22 & 25,05 & & & & & \\
\hline & 3.İngilizce & 21 & 25,43 & & & & & \\
\hline & 4.Türkçe & 20 & 24,10 & & & & & \\
\hline & 5.Sosyal Bilgiler & 25 & 24,56 & & & & & \\
\hline & 6.Fen Bilimleri & 21 & 23,14 & & & & & \\
\hline & 7.Din Kültürü & 22 & 25,59 & & & & & \\
\hline & 8.Diger & 18 & 24,83 & & & & & \\
\hline & 1.Akdeniz & 51 & 24,31 & \multirow{7}{*}{--- } & \multirow{7}{*}{5,235} & \multirow{7}{*}{6} & \multirow{7}{*}{0,514} & \\
\hline & 2.Ege & 23 & 25,00 & & & & & \\
\hline & 3.Doğu Anadolu & 32 & 25,16 & & & & & \\
\hline & 4.İç Anadolu & 25 & 25,48 & & & & & \\
\hline & 5.Güneydoğu Anadolu & 28 & 23,96 & & & & & \\
\hline & 6.Marmara & 26 & 24,85 & & & & & \\
\hline & 7.Karadeniz & 17 & 24,88 & & & & & \\
\hline
\end{tabular}

Tablo 8 incelendiğinde, öğretmenin çalıştığı öğretim kademesinin $\left(X^{2}=1,601, \quad \mathrm{p}>.05\right)$, öğretmenlerin kıdeminin $\left(X^{2}=3,673, p>05\right)$, öğretmenin branşının $\left(X^{2}=10,828, p>.05\right)$ ve öğretmenin dünyaya geldiği coğrafi bölgenin $\left(X^{2}=5,235, \mathrm{p}>.05\right)$ Araştırmacı altölçeğinde anlamlı farklılık yaratmadığı görülmüştür. Fakat cinsiyetin Araştırmacı altölçeği açısından anlamlı farklılık yarattığı görülmüştür (MWU=3990,500, p<.05). Bu farklılık kadın öğretmenlerle $(\bar{X}=24,30)$ erkek öğretmenler $(\bar{X}=25,28)$ arasında erkek öğretmenler lehinedir. Öngörülü ve İçten Olma altölçeğine ilişkin analiz sonuçları Tablo 9'da özetlenmiştir. 
Tablo 9. Çeşitli Değişkenler Bakımından Öngörülü ve İçten Olma (ÖİO)

\begin{tabular}{|c|c|c|c|c|c|c|c|c|}
\hline & Değişkenler & $\mathbf{N}$ & $\bar{X}$ & $\begin{array}{c}\text { Mann } \\
\text { Whitney } \\
\text { U }\end{array}$ & $\begin{array}{c}\text { Kruskal } \\
\text { Wallis } X^{2}\end{array}$ & sd & $\mathbf{p}$ & $\begin{array}{c}\text { Anlamlı } \\
\text { Fark }\end{array}$ \\
\hline \multirow{23}{*}{ 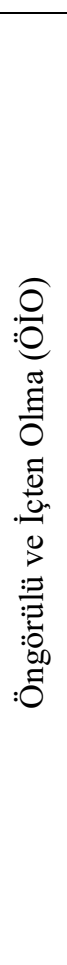 } & 1.Kadın & 112 & 16,57 & \multirow{2}{*}{4518,500} & \multirow[b]{2}{*}{---} & \multirow{2}{*}{--- } & \multirow{2}{*}{0,202} & \\
\hline & 2.Erkek & 90 & 16,99 & & & & & \\
\hline & 1.İlkokul & 53 & 16,55 & \multirow{3}{*}{---} & \multirow{3}{*}{2,013} & \multirow{3}{*}{2} & \multirow{3}{*}{0,366} & \\
\hline & 2.Ortaokul & 84 & 17,00 & & & & & \\
\hline & 3.Lise & 65 & 16,62 & & & & & \\
\hline & $1.1-10 \mathrm{Y}_{11}$ & 85 & 17,46 & \multirow{3}{*}{---} & \multirow{3}{*}{14,052} & \multirow{3}{*}{2} & \multirow{3}{*}{0,001} & \multirow{3}{*}{$1-2,1-3$} \\
\hline & $2.11-20 Y_{1} l$ & 71 & 16,17 & & & & & \\
\hline & 3.21 Yil ve Ustu & 46 & 16,37 & & & & & \\
\hline & 1.Sınıf Öğretmeni & 53 & 16,60 & \multirow{8}{*}{--- } & \multirow{8}{*}{10,251} & \multirow{8}{*}{7} & \multirow{8}{*}{0,125} & \\
\hline & 2.Matematik & 22 & 16,73 & & & & & \\
\hline & 3.İngilizce & 21 & 16,71 & & & & & \\
\hline & 4.Türkçe & 20 & 17,50 & & & & & \\
\hline & 5.Sosyal Bilgiler & 25 & 16,04 & & & & & \\
\hline & 6.Fen Bilimleri & 21 & 15,95 & & & & & \\
\hline & 7.Din Kültürü & 22 & 18,00 & & & & & \\
\hline & 8.Diger & 18 & 16,89 & & & & & \\
\hline & 1.Akdeniz & 51 & 16,75 & \multirow{7}{*}{---} & \multirow{7}{*}{11,248} & \multirow{7}{*}{6} & \multirow{7}{*}{0,081} & \\
\hline & 2.Ege & 23 & 17,87 & & & & & \\
\hline & 3.Doğu Anadolu & 32 & 17,13 & & & & & \\
\hline & 4.İc Anadolu & 25 & 16,32 & & & & & \\
\hline & 5.Güneydoğu Anadolu & 28 & 15,96 & & & & & \\
\hline & 6.Marmara & 26 & 16,19 & & & & & \\
\hline & 7.Karadeniz & 17 & 17,41 & & & & & \\
\hline
\end{tabular}

Tablo 9 incelendiğinde, cinsiyetin, (MWU=4518,500, p>.05), öğretmenin öğretmenin çalıştığ ögretim kademesinin $\left(X^{2}=2,013, \mathrm{p}>.05\right)$, ögretmenin branşının $\left(X^{2}=10,251, \mathrm{p}>.05\right)$ ve öğretmenin dünyaya geldiği coğrafi bölgenin $\left(X^{2}=11,248, \mathrm{p}>.05\right)$ Öngörülü ve İçten Olma altölçeğinde anlamlı farkl1lık yaratmadığı görülmüştür. Fakat öğretmenin kıdeminin Öngörülü ve İçten Olma açısından anlamlı farklılık yarattığı görülmüştür $\left(X^{2}=14,052, \mathrm{p}<05\right) .1-10$ y1l kıdeme sahip öğretmenler $(\bar{X}=17,46), 11-20$ y1l kıdeme sahip öğretmenlere göre $(\bar{X}=16,17)$ ve 21 y1l ve üstü kıdeme sahip öğretmenlere göre $(\bar{X}=16,37)$ Öngörülü ve İçten Olma altölçeğinde daha yüksek ortalamalara sahiptirler. Mesleğe Bakış altölçeğine ilişkin analiz sonuçları Tablo 10'da özetlenmiştir.

Tablo 10. Çeşitli Değişkenler Bakımından Mesleğe Bakış (MB)

\begin{tabular}{|c|c|c|c|c|c|c|c|c|}
\hline & Değişkenler & $\mathbf{N}$ & $\bar{X}$ & $\begin{array}{c}\text { Mann } \\
\text { Whitney } \\
\text { U }\end{array}$ & $\begin{array}{c}\text { Kruskal } \\
\text { Wallis } X^{2}\end{array}$ & sd & $\mathbf{p}$ & $\begin{array}{c}\text { Anlamlı } \\
\text { Fark }\end{array}$ \\
\hline \multirow{15}{*}{ 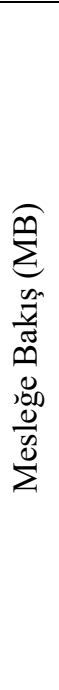 } & $\begin{array}{l}\text { 1.Kadın } \\
\text { 2.Erkek }\end{array}$ & $\begin{array}{l}112 \\
90\end{array}$ & $\begin{array}{l}7,39 \\
8,28\end{array}$ & 3628,000 & -- & -- & 0,000 & $1-2$ \\
\hline & 1.İlkokul & 53 & 8,34 & \multirow{3}{*}{---} & \multirow{3}{*}{7,349} & \multirow{3}{*}{2} & \multirow{3}{*}{0,025} & \multirow{3}{*}{$1-3$} \\
\hline & 2.Ortaokul & 84 & 7,88 & & & & & \\
\hline & 3.Lise & 65 & 7,22 & & & & & \\
\hline & 1.1-10 Y1l & 85 & 7,66 & \multirow{3}{*}{--- } & \multirow{3}{*}{3,133} & \multirow{3}{*}{2} & \multirow{3}{*}{0,209} & \\
\hline & $2.11-20 \mathrm{Y} 1 \mathrm{l}$ & 71 & 7,65 & & & & & \\
\hline & 3.21 Yil ve Ustu & 46 & 8,24 & & & & & \\
\hline & 1.Sınıf Öğretmeni & 53 & 7,96 & \multirow{8}{*}{--- } & \multirow{8}{*}{9,215} & \multirow{8}{*}{7} & \multirow{8}{*}{0,238} & \\
\hline & 2.Matematik & 22 & 8,14 & & & & & \\
\hline & 3.İngilizce & 21 & 7,90 & & & & & \\
\hline & 4.Türkçe & 20 & 7,40 & & & & & \\
\hline & 5.Sosyal Bilgiler & 25 & 8,68 & & & & & \\
\hline & 6.Fen Bilimleri & 21 & 7,95 & & & & & \\
\hline & 7.Din Kültürü & 22 & 6,55 & & & & & \\
\hline & 8.Diger & 18 & 7,22 & & & & & \\
\hline
\end{tabular}




\begin{tabular}{|c|c|c|c|c|c|c|c|}
\hline 1.Akdeniz & 51 & 7,94 & & & & & \\
\hline 2.Ege & 23 & 6,87 & & & & & \\
\hline 3.Doğu Anadolu & 32 & 6,97 & & & & & \\
\hline 4.İç Anadolu & 25 & 8,72 & --- & 17,880 & 6 & 0,007 & $2-4,3-4$ \\
\hline 5.Güneydoğu Anadolu & 28 & 7,93 & & & & & \\
\hline 6.Marmara & 26 & 8,42 & & & & & \\
\hline 7.Karadeniz & 17 & 7,53 & & & & & \\
\hline
\end{tabular}

Tablo 10 incelendiğinde, öğretmenlerin sahip olduğu k1demin $\left(X^{2}=3,133, \mathrm{p}>05\right)$ ve öğretmenlerin branşının $\left(X^{2}=9,215, \mathrm{p}>.05\right)$ Mesleğe Bakış altölçeğinde anlamlı farklılık yaratmadığı görülmüştür. Fakat cinsiyetin (MWU $=3628,000, \mathrm{p}<.05)$, öğretmenin çalıştığ öğretim kademesinin $\left(X^{2}=2,013, \mathrm{p}<.05\right)$ ve öğretmenin doğduğu coğrafi bölgenin $\left(X^{2}=17,880, p<.05\right)$ Mesleğe Bakış açısından anlamlı farklılık yarattığı görülmüştür. Öncelikle, bu farklılık kadın öğretmenlerle $(\bar{X}=7,39)$ erkek öğretmenler $(\bar{X}=8,28)$ arasında erkek öğretmenler lehinedir. İkinci olarak, bu farklılık ilkokulda görev yapan öğretmenlerle $(\bar{X}$ $=8,34)$ lisede görev yapan öğretmenler $(\bar{X}=7,22)$ arasında ilkokulda görev yapan öğretmenler lehinedir. Son olarak, İç Anadolu Bölgesi'nde dünyaya gelen öğretmenlerin mesleğe bakış yansitıcı düşünme eğilimi Doğu Anadolu ve Ege Bölgesi’nde dünyaya gelen öğretmenlerden daha yüksektir.

\section{TARTIŞMA ve SONUÇ}

Öğretmenlerin sahip olduğu nitelikler, eğitim sisteminin şekillenmesinde son derece önemlidir. Bu bakımdan, öğretmenlerin yansıtıcı düşünme becerileri, öğretmenlerin ve öğretme öğrenme sürecinin niteliğinde etkili olduğu düşünülen özelliklerdendir. Araştırmada ilkokul, ortaokul ve lise kademelerindeki öğretmenlerin yansıtıcı düşünme eğilimlerinin belirlenmesi amaçlanmıştır. Bu amaca ulaşmak için ilk önce yansıtıcı düşünme eğilimleri hakkında mevcut durum betimlenmiş, sonrasında ise çeşitli değişkenler açısından incelenmeye çalışılmıştır.

21. yüzyılda öğretmenlerden eleştirel ve yanstıcı düşünme becerilerini kazanmış, sorgulayan ve yorumlama yetileri gelişmiş bireyler olmaları beklenmektedir. Bu araştırmada öğretmenlerin yansıtıcı düşünme eğilimlerinin üst düzeye yakın olduğu tespit edilmiştir. Bu bulguyla paralel sonuçlara sahip olan diğer çalışmalarda da öğretmenlerin yansitıcı düşünme düzeylerinin yüksek olduğu görülmüsstür (Aslan, 2009; Aydın ve Çelik, 2008; Dolapçığlu, 2007; Duban, Yelken, Durdukoca ve Demir, 2012; 2010; Hasırc1 ve Sadık, 2011; Karadağ, 2010). Çam Aktaş (2016) ise pedagojik formasyon programı öğrencileri ile ilgili bir çalışma yürütmüş ve formasyon öğrencilerinin yansıtıcı düşünme eğilimlerinin mesleğe bakış alt boyutu dışında yüksek olduğu, mesleğe bakış boyutunda ise orta düzeyde olduğunu vurgulamıştır. Üstün'ün (2011) yaptığı araştırmada ise öğretmenlerin yansıtıcı düşünme eğilimi kapsamında açık fikirlilik boyutunda yüksek puanlar aldıkları, öğretim sorumluluğu ve bilimsellik boyutundan ise düşük puanlar aldıkları vurgulanmıştır. Köstekçi'nin (2016) çalışmasında da yansıtıcı düşünme eğilimi kapsamında öğretmen adaylarının en yüksek puanlarının "Sorgulayıcı ve Etkili Öğretim” alt boyutunda olduğu görülmektedir.

Öğretmenlerin yansıtıcı düşünme eğilimlerine yönelik görüşleri cinsiyet değişkeni açısından incelendiğinde, açık fikirlilik, araştırmacı ve mesleğe bakış alt boyutlarında erkek öğretmenler lehinde farklılaşmaktadır. Bu alt boyutlardaki farklılıklar erkek öğretmenlerin bağımsız düşünmeye ve araştırmaya daha çok eğilim gösterdiklerini göstermektedir. Ayrıca bu özelliklerin erkek öğretmenlerin mesleğe olan bakış açılarını da olumlu etkilediği sonucuna ulaşılmıştır. Şanlı (2016) tarafından öğretmen adaylarının yansıtıcı düşünme eğilimlerinin araştırıldığ çalışmada, cinsiyet değişkeni açısından anlamlı farklılıklar tespit edilmiştir. Araştırmamızla paralel olarak, erkek öğretmen adaylarının kadın öğretmen adaylarına göre daha fazla yansıtıcı düşünme eğiliminde oldukları, açık fikirlilik ve mesleğe bakış alt boyutlarında da daha yüksek puanlar aldıkları görülmüştür. Fakat, Karadağ (2010), Şahin (2011) ve Dolapçığlu (2007) tarafından yapılan çalışmalarda öğretmenlerin yansıtıcı öğretmen özelliklerine sahip olma düzeylerinde cinsiyetlerine göre genel olarak anlamlı bir farklılık göstermediği sonucuna ulaşmışlardır. Benzer şekilde, Gedik, Akhan ve Kılıçoğlu (2014) ve Güvenç (2012) tarafından yapılan çalışmalarda cinsiyet değişkeninin öğretmen adaylarının yansıtıcı düşünme eğilimlerinde anlamlı bir fark yaratmadığı bulunmuştur. Ayrıca, Köstekçi'nin (2016) çalışmasında kadın öğretmen adaylarının erkek öğretmen adaylarına göre daha çok yansıtıcı düşünme eğilimlerinin olduğu; Keskinkılıç Yumuşak'ın (2015) çalışmasında ise açık fikirlilik ve sorgulayıcı ve etkili öğretim altboyutlarında kızların erkeklere göre daha yüksek düzeyde yansıtıcı düşünme eğilimlerinin olduğu ifade edilmiştir. Çam Aktaş'ın çalışmasında (2016) da pedagojik formasyon programı öğrencilerinin yansıtıcı düşünme düzeyleri cinsiyete göre yalnızca açık fikirlilik alt boyutunda anlamlı düzeyde farklılaştı̆̆ gözlemlenmiştir. 
Keskinkılıç Yumuşak'ın (2015) çalışmasında mesleğe ilişkin tutumun "değer" boyutu ile yansıtıcı düşünmenin araştırmacılık boyutu ile pozitif yönde anlamlı bir ilişki olduğu görülmektedir. Mesleğe ilişkin tutumun "uyum" boyutu ile sürekli ve amaçlı düşünme, açık fikirlilik, sorgulayıcı ve etkili öğretim, öğretim sorumluluğu ve bilimsellik, mesleğe bakış arasında pozitif yönde anlamlı bir ilişki olduğu bulunmuştur. Öğretmenlik mesleğine yönelik tutum ile yansıtıcı düşünme eğilimi arasında anlamlı bir ilişki olduğu görülmektedir.

Öğretmenlerin yansıtıcı düşünme eğilimleri branş değişkenine göre farklılık göstermemektedir. K1dem değişkenine göre ise öğretmenlerin yansitıcı düşünme eğilimleri, öğretim sorumluluğu ve bilimsellik ile öngörülü ve içten olma alt boyutlarında farklılaşmaktadır. Elde edilen bulgular, kıdemi düşük olan öğretmenlerin kıdemi yüksek öğretmenlerle kıyaslandığında, öğretim sorumluluğu ile hareket ederek bilimsel bakış açısıyla öğrencilerin beklentilerine cevap verme eğilimde oldukları ve sınıfta etkili iletişim ortamı kurarak öğrencileri geleceğe hazırlama noktasında onlara rehberlik yapma bilinci içinde hareket ettikleri yorumu yapılabilir. Dolayısıyla, kıdemi düşük olan öğretmenlerin, diğer kıdemdeki öğretmenlere göre öğrenme sürecini daha etkili ve bilinçli yönlendirdirdikleri ve katı, değişmez uygulamalar yerine esnek programla alternatif çözümler temelinde etkili eğitim ortamları oluşturdukları söylenebilir. Bu durum, mesleğinin ilk yıllarında olan öğretmenlerin aldıkları güncel eğitimle kuramsal boyutu eyleme dönüştürmede daha başarılı olmalarından ve modern eğitim anlayışını daha fazla benimsemelerinden kaynaklanıyor olabilir.

Araştırmada, en fazla farklılık gösteren değişkenin kademe olduğu gözlenmiştir. Sürekli ve amaçlı düşünme, açık fikirlilik, sorgulayıcı ve etkili öğretim ve mesleğe bakış alt boyutlarında tespit edilen farklıklar sonucunda ortaokul ve ilkokul kademelerindeki öğretmenlerin lise kademesindeki öğretmenlere göre daha fazla yansitıcı düşünme eğilimlerini gösterdikleri görülmektedir. $\mathrm{Bu}$ durum, ilkokul ve ortaokulda yansıtıcı düşünmeyi benimsemiş öğretmenlerin öğrencileri için etkili bir eğitim ortamı oluşturarak onların aktif olarak eğitim sürecinin parçası olmasını sağlamaya çalıştıkları şeklinde yorumlanabilir. Durdukoca ve Demir (2010)'in çalışmasında da ilköğretim öğretmenlerinin yüksek düzeyde yansitıcı düşünme becerilerine sahip olduğu görülmektedir. Bu bulguya paralel olarak, Köstekçi'nin (2016) çalışmasında da öğretmen adaylarından en yüksek yansıtıcı düşünme düzeylerine sahip olanların sınıf öğretmenliğine devam eden öğretmen adayları oldukları ortaya çıkmıştır. Üstün (2011)'nin çalışmasında ise sınıf öğretmenlerinin yansıtıcı düşünme eğilimi açısından en yüksek puanı "açık fikirlilik" alt boyutundan aldıkları, kadın öğretmenlerin erkek öğretmenlere göre daha yüksek bir yansıtıcı düşünme eğilimi gösterdikleri ve sınıf öğretmenlerinin görev yaptıkları okul türü ve kıdem değişkenlerinin yansıtıcı düşünme eğilimi açısından anlamlı farklılık oluşturduğu tespit edilmiştir. Kandemir (2015)'in araştırmasında elde edilen sonuçlara göre hem sınıf hem de ilköğretim matematik öğretmen adaylarının yansıtıcı düşünme eğilim düzeyleri çok yüksek bulunmuştur.

Öğretmenlerin yansıtıcı düşünme eğilimleri bölge değişkenine göre, sorgulayıcı ve etkili öğretim ile mesleğe bakış alt boyutlarında farklılaşmaktadır. Özellikle Güney Doğu Anadolu ve Karadeniz Bölgeleri'nin diğer bölgelere göre daha düşük ortalamaya sahip olması, bu bölgelerin güçlü kültürel özellikleri, kolektivist yapısı ve bölgedeki daha geleneksel öğretim anlayışına bağlanabilir. Gedik, Akhan ve Kılıçoğlu (2014) ile Aydın ve Çelik'in (2013) çalışmalarında ailenin gelirinin yansıtıcı düşünme eğiliminde farklılaşmaya yol açıp açmadıklarını incelemişler ve ailenin sosyo-ekonomik düzeyinin Sosyal Bilgiler oğretmen adaylarının yansıtıcı düşünme eğilimlerine etkisi olmadığını gözlemlemişlerdir. Ayrıca, Gedik ve diğerleri (2014) Sosyal Bilgiler öğretmen adaylarının mezun oldukları lise türüne göre yansıtıcı düşünme eğilimi ölçeği boyutlarından olan sürekli ve amaçlı düşünme alt boyutunda anlamlı farklılık gösterdiğini, sıra ortalamaları dikkate alındığında en yüksek düzeyde olan yansıtıcı düşünme eğilimi olanların Anadolu Lisesi mezunu oldukları görülmüştür. Çam Aktaş'ın (2016) pedagojik formasyon programı öğrencileri ile ilgili yaptığı araştırmada ise formasyon öğrencilerinin örgün eğitim ya da uzaktan eğitim mezunu olmalarının yansıtıcı düşünme düzeyleri açısından farklılaşma meydana getirmediği görülmüştür.

İleride yapılacak araştırmalar için yansıtıcı düşünme eğilimini geliştirecek etkinlikler, öğretmenlerin üstbilişsel düşünme becerilerinin yansıtıcı düşünme üzerindeki etkisi araştırılabilir. Ayrıca, öğretmenlerin eğitim inançları ile yansıtıcı düşünme eğilimleri arasında bir ilişki olup olmadığı incelenebilir. Korelasyon çalışmalarının yanı sıra gözlem ve görüşmeye dayalı nitel çalışmalar da yapılabilir. Yansıtıcı düşünme eğilimi üzerinde durularak, alternatif bilgi edinme yöntemlerine ve gerçeğin çoğulcu yapısına vurgu yapan çalışmalar yapılabilir. Yansıtıcı düşünme eğilimi ölçeklerinin her bir alt boyutu daha etkili bir şekilde inceleyebilmek için ayrı birer araştırma konusu olabilir. Öğretmenlerin eğitim öğretim ortamlarını yeniden 
yapılandırmaları ve kendilerini geliştirmeleri için güncel olayları ve gündemi takip etmeleri farklı eğitim perspektiflerinin eğitim ortamına yansımasını sağlayabilir. 


\section{KAYNAKLAR}

Alp, S., \& Taşkın, Ş. Ç. (2008). Eğitimde yansıtıcı düşünmenin önemi ve yansıtıcı düşünmeyi geliştirme. Milli Eğitim Dergisi, 178, 311-320.

Aslan, G. (2009). Sinıf Öğretmenlerinin yansıtıcı düşünme eğilimleri ile sürekli kaygı düzeyleri arasındaki ilișkinin incelenmesi. Yayınlanmamış yüksek lisans tezi. İstanbul: Yeditepe Üniversitesi Sosyal Bilimler Enstitüsü.

Aydın, M., ve Çelik, T. (2013). Sosyal Bilgiler öğretmen adaylarının yansıtıcı düşünme becerilerinin bazı değişkenler açısından incelenmesi. Pamukkale Üniversitesi Eğitim Fakültesi Dergisi, 34/II, 169-181.

Başol, G. ve Evin Gencel, İ. (2013). Yansitıcı düşünme düzeyini belirleme ölçeği: geçerlik ve güvenirlik çalışması. Kuram ve Uygulamada Eğitim Bilimleri Dergisi, 13 (2), 929-946.

Büyüköztürk, Ş. (2013). Sosyal bilimler için veri analizi el kitabı. Ankara: Pegema Yayınları.

Çam Aktaş, B. (2016). Pedagojik formasyon programı öğrencilerinin eleştirel okuma özyeterlik algisi ve yansitici düşünme eğilimlerinin incelenmesi. Elektronik Sosyal Bilimler Dergisi, 15(59), 1186-1202.

Çubukçu, Z. (2011) Düşünme Becerileri. Filiz, S. B. (Ed.) Ögrenme öğretme kuram ve yaklaşımları. Ankara: Pegem Akademi Yayıncilık.

Demiralp, D. (2010). İlköğretim birinci kademe programlarını öğrencilerin yansitıcı düşünmelerini geliştirmeye etkisine yönelik öğretmen görüşleri. Yayınlanmış yüksek lisans tezi. Elazı̆̆: Fırat Üniversitesi, Sosyal Bilimler Enstitüsü.

Deryakulu, D. (2004). Epistemolojik inançlar. Eğitimde bireysel farkllılklar. Ankara: Nobel Yayınevi.

Dewey, J. (1933). How we think. Boston: Heath.

Dolapçıŏlu, S. D. (2007). Sınıf öğretmenlerinin yansıtıcı düşünme düzeylerinin değerlendirilmesi. Yayınlanmamış yüksek lisans tezi, Mustafa Kemal Üniversitesi, Sosyal Bilimler Enstitüsü, Hatay.

Duban, N., \& Yelken T. Y. (2010). Öğretmen adaylarının yansıtıcı düşünme eğilimleri ve yansıtıcı öğretmen özellikleriyle ilgili görüşleri. Çukurova Üniversitesi Sosyal Bilimler Enstitüsü Dergisi, 19(2), 343-336.

Durdukoca, F. Ş., \& Demir, M. (2012). İlköğretim öğretmenlerin bazı değişkenlere göre yansıtıcı düşünme düzeyleri ve düşüncelerindeki öğretmen niteliklerinin yansıtıcı öğretmen niteliklerine uygunluğu. Mustafa Kemal Üniversitesi Sosyal Bilimler Enstitüsü, 9 (20), 357-374.

Ersözlü, Z. N. (2008). Yansitıcı düşünmeyi gelişstirici etkinliklerin ilköğretim 5. sinıf öğrencilerinin sosyal bilgiler dersindeki akademik başarılarına ve tutumlarına etkisi. Yayınlanmamış doktora tezi. Elazığ: Firat Üniversitesi, Sosyal Bilimler Enstitüsü.

Gedik, H., Akhan, N. ve Kılıçoğlu, G. (2014). Sosyal bilgiler öğretmen adaylarının yansıtıcı düşünme eğilimleri. Mediterranean Journal of Humanities, 4(2), 113-130.

Genç, B. (2004). The Nature of reflective thinking and its implications for in-service teacher education. Çukurova Üniversitesi Sosyal Bilimler Enstitüsü Dergisi, 13, 235-243.

Green, S. B. ve Salkind, N. J. (2008). Using SPSS for Windows and Macintosh. Pearson Prentice Hall. New Jersey.

Güvenç, Z. (2012). Sinıf öğretmenlerinin duygusal zekâları ile yansıtıcı düşünme becerileri arasındaki iliş̧ki. Yüksek lisans tezi, Pamukkale Üniversitesi, Sosyal Bilimler Enstitüsü, Denizli

Hasırcı, K. Ö., \& Sadık, F. (2011). Sınıf öğretmenlerinin yansıtıcı düşünme eğilimlerinin incelenmesi. Çukurova .Üniversitesi. Sosyal Bilimler Enstitüsü Dergisi, 20 (2) 195-210.

Kandemir, M. A. (2015). İlköğretim matematik ve sınıf öğretmeni adaylarının yansıtıcı düşünme eğilim düzeylerinin bazı değişkenlere göre incelenmesi. NWSA-Education Sciences, 10(4), 253-275.

Karadağ, M. (2010). Sosyal bilgiler ögretmenlerinin yansitıcı düsünme düzeylerinin incelenmesi (Şanlıurfa İli Örneği). Yayınlanmamış yüksek lisans tezi, Çukurova Üniversitesi Sosyal Bilimler Enstitüsü, Adana.

Karasar, N. (2000). Bilimsel araştırma yöntemi-kavramlar, ilkeler, teknikler. 10.Baskı. Ankara: Nobel Yayınevi.

Keskinkılıç-Yumuşak, G. (2015). Öğretmen adaylarının yansıtıcı düşünme eğilimleri ve mesleğe yönelik tutumları. Bartın Üniversitesi Ĕ̈itim Fakültesi Dergisi, 4(2), 466-481.

Köstekçi, E. (2016). Öğretmen adaylarının giriş̧imcilik özellikleri ile yansıtıcı düşünme düzeyleri arasındaki ilişkinin incelenmesi. Yüksek Lisans Tezi, Bartın Üniversitesi, Bartın. 
Rodgers, C. (2002). Defining reflection: another look at John Dewey and reflective thinking. Teachers College Record, 104 (4), 842-866.

Semerci, Ç. (2007). Öğretmen ve öğretmen adayları için yansıtıcı düşünme eğilimi (YANDE) ölçeğinin geliştirilmesi. Kuram ve Uygulamada Ĕ̌itim Bilimleri, 7(3), 1351-1377.

Semerci, N. (1999). Kritik düşünmenin mikro ögrretim dersinde eleştiri becerisini geliştirmeye etkisi. Yayınlanmamış doktora tezi, Fırat Üniversitesi Sosyal Bilimler Enstitüsü, Elazı̆̆.

Şahin, A. (2011). Türkçe öğretmeni adaylarının yansıtıcı düşünme eğilimlerinin çeşitli değişkenlere göre değerlendirilmesi. Elektronik Sosyal Bilimler Dergisi, 10 (37), 108-119.

Şanlı Ş. (2016). Öğretmen adaylarının yansıtıcı düşünme eylemlerinin bazı değişkenler açısından değerlendirilmesi. Yayınlanmamış yüksek lisans tezi, Akdeniz Üniversitesi Eğitim Bilimleri Enstitüsü, Antalya.

Ünver, G. (2010). Yansıtıcı düşünme: Eğitimde yeni yönelimler. (Ed: Özcan Demirel). Ankara: Pegem Akademi Yayınları.

Üstün, G. (2011). Sınıf öğretmenlerinin yansıtıcı düşünme eğilimleri ile demokratik tutumları arasındaki ilişkinin incelenmesi. Yayınlanmamış yüksek lisans tezi, Marmara Üniversitesi Eğitim Bilimleri Enstitüsü, İstanbul.

Üstünlüoğlu, E. (2006). Üst düzey düşünme becerilerini geliştirmede bilişsel soruların rolü. Çağdaş Eğitim Dergisi, $31(331), 17-24$ 